\title{
Effect of $\gamma$ aminobutyric acid on the carbon dioxide rebreathing response of normal subjects: a study using vigabatrin
}

\author{
A G Fennerty, E M Rimmer, J Boulton, A Richens
}

\begin{abstract}
Animal studies suggest that $\gamma$ aminobutyric acid (GABA) may be an important neurotransmitter in the control of respiration. Vigabatrin, a new drug for the treatment of epilepsy, is thought to exert its effect by increasing GABA concentrations in the brain. To assess the effect of increased GABA concentrations in the brain on human respiration we measured the ventilatory response to carbon dioxide in seven normal subjects after they had taken vigabatrin or placebo for three days in a double blind crossover study. There was no change in either the slope or the intercept of the curve of the ventilatory response to carbon dioxide after vigabatrin by comparison with placebo. This study suggests that GABA does not have an important role in the control of respiration in normal individuals.
\end{abstract}

Gamma aminobutyric acid (GABA) is a major inhibitory neurotransmitter found in high concentrations in many areas of the brain. There is some evidence that it may be implicated in the control of respiration. When GABA is directly applied ventrocisternally to anaesthetised $\operatorname{dogs}^{1}$ or infused into the cisterna magna or fourth ventricle of anaesthetised cats, ${ }^{2}$ there is a reduction in inspiratory force and a fall in tidal volume. In anaesthetised rats a reduction in breathing frequency and an inverse relation between respiratory drive and brainstem GABA concentrations has been found. ${ }^{3}$ In dogs medullary GABA concentrations increase after one to two hours of hypercapnia ${ }^{4}$ and it has been suggested that rising GABA concentrations may serve to modulate the effect of a rising carbon dioxide concentration in a negative feedback loop. ${ }^{1}$ The effect of increasing brain GABA concentrations on human respiration is not known, because GABA cannot be instilled directly into the brain and peripherally administered GABA does not cross the blood-brain barrier. Vigabatrin is a novel antiepileptic drug, ${ }^{5}$ which prevents the breakdown of GABA by irreversibly binding with the enzyme GABA transaminase; thus it is thought to exert its effect by increasing brain GABA concentrations. It is known to increase the concentration of the GABA in the brain in rats ${ }^{6}$ and in the cerebrospinal fluid in man. ${ }^{7}$ We used this drug to see if increasing GABA concentrations in the brain might depress the ventilatory response to carbon dioxide, in an attempt to assess whether GABA has a role in the control of ventilation in man.

\section{Methods}

Seven fit subjects (two female), mean age 30 (range 26-35) years, took vigabatrin $3 \mathrm{~g}$ daily or placebo for three days, with a 14 day washout period, in a randomised double blind crossover study. The dose chosen is known to have an appreciable antiepileptic effect when taken long term, ${ }^{5}$ and a reduction of photosensitivity in epileptic patients has been shown after a single $3 \mathrm{~g}$ dose. ${ }^{8}$ Drug compliance was confirmed by measurment of the plasma concentration of the drug and pharmacological activity was assessed in four patients by measurement of platelet GABA transaminase activity; ${ }^{9}$ this is thought to reflect activity in the brain and consequently to relate indirectly to brain GABA concentrations. ${ }^{10}$

For assessment of the ventilatory response to carbon dioxide subjects were familiarised with the apparatus. They sat quietly for 10 minutes before being attached to the mouthpiece and switched into a closed "bag in box" system (a 6 litre bag containing 5\% carbon dioxide and $95 \%$ oxygen) at the end of expiration. End tidal carbon dioxide tension $\left(\mathrm{PCO}_{2}\right)$ was measured with a rapid response infrared analyser ( $P$ K Morgan, Rainham, Kent) and tidal volume was measured with a rotating vane anemometer on the inspiratory limb of a valve box attached to the mixing chamber.

Breath by breath end tidal $\mathrm{PCO}_{2}$ was plotted against minute volume via a data logger and computer system (P K Morgan, Rainham, Kent); the slope of the response was calculated from the least square regression line. The subjects rebreathed to an end tidal carbon dioxide concentration of 8.5-9\% and the mean of two ventilatory response curves was used for analysis. The coefficient of variation for paired responses was $14 \%$ for the slope of the carbon dioxide ventilatory response and $6 \%$ for the intercept; for responses separated by time the coefficients of variation were $22 \%$ and $9 \%$ respectively. Limited data were available on the breathing pattern but tidal volume and breathing frequency were 
Slope and intercept of the ventilatory response to carbon dioxide and platelet $\gamma$ aminobutyric acid $(G A B A)$ transaminase activity after placebo $(P)$ and vigabatrin $(V)$

\begin{tabular}{|c|c|c|c|c|c|c|c|}
\hline \multirow[b]{2}{*}{ Subject No } & \multirow[b]{2}{*}{$\begin{array}{l}\text { Treatment order } \\
\text { (PorV first) }\end{array}$} & \multicolumn{2}{|l|}{ Placebo } & \multicolumn{2}{|l|}{ Vigabatrin } & \multicolumn{2}{|c|}{$\begin{array}{l}\text { Platelet } G A B A \text { transaminase } \\
\text { activity (pmol } / \text { min } / \mathrm{mg} \text { protein) }\end{array}$} \\
\hline & & $\begin{array}{l}\text { Slope } \\
(l / \min \mid k P a)\end{array}$ & $\begin{array}{l}\text { Intercept } \\
\left({ }_{0}^{o} C \mathrm{O}_{2}\right)\end{array}$ & $\begin{array}{l}\text { Slope } \\
(l / \min / k P a)\end{array}$ & $\begin{array}{l}\text { Intercept } \\
\left({ }_{o}^{o} C \mathrm{O}_{2}\right)\end{array}$ & Placebo & Vigabatrin \\
\hline $\begin{array}{l}1 \\
2 \\
3 \\
4 \\
5 \\
6 \\
7\end{array}$ & $\begin{array}{l}V \\
V \\
P \\
P \\
P \\
V \\
V\end{array}$ & $\begin{array}{r}21.0 \\
16.5 \\
18.4 \\
14.9 \\
8.5 \\
21.0 \\
9.7\end{array}$ & $\begin{array}{l}7.4 \\
7.5 \\
5.6 \\
6.5 \\
6.0 \\
5.6 \\
5.5\end{array}$ & $\begin{array}{r}19.5 \\
13 \cdot 2 \\
28.0 \\
6.4 \\
7.4 \\
20.8 \\
13.6\end{array}$ & $\begin{array}{l}5 \cdot 8 \\
6 \cdot 8 \\
6 \cdot 6 \\
6 \cdot 8 \\
6 \cdot 1 \\
5 \cdot 6 \\
6 \cdot 0\end{array}$ & $\begin{array}{l}27 \cdot 2 \\
18 \cdot 6 \\
11 \cdot 6 \\
14 \cdot 1\end{array}$ & $\begin{array}{l}3.9 \\
3.7 \\
0 \\
4.4\end{array}$ \\
\hline Mean (SD) & & $15 \cdot 7(5 \cdot 0)$ & $6.3(0.9)$ & $15 \cdot 6(7 \cdot 7)$ & $6 \cdot 2(0.5)$ & $17 \cdot 8(6.9)$ & $3.0(2.0)$ \\
\hline
\end{tabular}

analysed before and during stimulated breathing. Results were analysed by means of Student's $t$ test.

\section{Results}

Drug compliance was confirmed by finding appropriate serum concentrations in blood taken two to three hours after a dose (mean (SD) $32.5(10.5) \mu \mathrm{m} / \mathrm{ml})$. In four subjects the mean GABA transaminase activity fell from $17.8(6.9) \mathrm{pmol}$ of product $/ \mathrm{min} / \mathrm{mg}$ protein with placebo to 3.0 (2) $\mathrm{pmol}$ of product $/ \mathrm{min} /$ $\mathrm{mg}$ protein with vigabatrin. Four subjects complained of drowsiness while taking vigabatrin, a well recognised side effect at the start of treatment. ${ }^{5}$

There was no significant effect of active drug on the slope of the carbon dioxide response curve or its intercept (table), the $95 \%$ confidence limits being $-5 \cdot 1$ to $+5.41 / \mathrm{min} /$ $\mathrm{kPa}$ for the difference between the mean of the slopes and $-2 \%$ to $+2.1 \%$ carbon dioxide for the intercept. Four subjects received active drug first; no order effect was noted. Active treatment had no significant effect on resting baseline breathing frequency (mean (SD) 8.7 $(2.4)$ breaths/min after placebo $v 9.4$ (1) breaths/min after vigabatrin) or on tidal volume $(670(130) \mathrm{ml} v 855(443) \mathrm{ml})$. There was no significant change in the slope of breathing frequency versus tidal volume during carbon dioxide rebreathing (3 (1.8) breaths $/ \mathrm{min} / 1$ versus $1 \cdot 8(1.4)$ breaths $/ \mathrm{min} / 1)$.

\section{Discussion}

Although vigabatrin had no significant effect on the carbon dioxide ventilatory response in these seven normal subjects, a small inhibitory effect may have been missed because of the poor between day reproducibility (as shown by the wide confidence limits) of the carbon dioxide rebreathing response. The dose of vigabatrin used in this study is sufficient to increase GABA concentrations in the brain; clinically it has been shown to have an appreciable antiepileptic effect. ${ }^{5-8}$ On the basis of studies in rats we would expect a twofold increase in total GABA concentrations in the brain for the degree of platelet inhibition achieved, ${ }^{10}$ and this would be substantially higher at the gabaergic nerve terminals. In brain perfusion studies respiration was inhibited by a topical concentration of GABA one to five times that estimated at the nerve terminal. ${ }^{1}$ Interpretation of the results of these studies is difficult, however, as anaesthetic agents were used, and these may themselves cause augmentation of gabaergic mechanisms.

This study looked primarily at the rebreathing response to carbon dioxide. Limited data are available for breathing patterns and this was obtained from subjects breathing through a mouthpiece. In animal perfusion studies GABA reduced tidal volume in cats and dogs, ${ }^{12}$ and reduced both tidal volume and breathing frequency in rats. ${ }^{3}$ No change in these measurements was evident after administration of vigabatrin during resting or stimulated breathing in our normal subjects. Although GABA may be unimportant in the control of normal respiration it may be important in disease. Medullary glutamine concentrations increase along with GABA in respiratory acidosis. ${ }^{4}$ Glutamine is a precursor for GABA and glutamic acid, an excitatory neurotransmitter. ${ }^{11}$ Differences in the pathway taken by glutamine, or the relative sensitivity of the respiratory centre to GABA, may explain why some subjects retain carbon dioxide and others, with similar degrees of airflow obstruction, maintain a high respiratory drive and near normal blood gas tensions. Investigations using vigabatrin and more sensitive tests of respiratory control should prove useful in further elucidating the role of GABA in the control of respiration.

We found no evidence of respiratory depression in healthy subjects using a recommended dose, but this finding may not be relevant to the clinical use of the drug-it may not apply to patients with lung disease or when the drug is being taken in higher dosage.

1 Kneussle MP, Pappaginopoulos P, Hoop B, Kaseris H. Reversible depression of ventilation and cardiovascular function by ventriculosternal perfusion with gammaaminobutyric acid in dogs. Am Rev Respir Dis 1986;

2 Yamada KA, Hamosh P, Gillis RA. Respiratory depression produced by activation of GABA receptors in hindbrain of cat. J Appl. Physiol 1981;51:1278-86.

3 Hedner J, Hedner T, Wessberg P, Jonason J. An analysis of the mechanism by which gamma-aminobutyric acid depresses ventilation in the rat. J Appl Physiol 1984; 56:849-56.

4 Hoop B, Shih VE, Kasseris H. Relationship between central nervous system hydrogen ion regulation and amino acid metabolism in Hypercapnia: II. Am Rev Respir Dis 1985;132:248-53. 
5 Rimmer EM, Richens A. Double-blind study of $\gamma$-vinyl GABA in patients with refractory epilepsy. Lancet 1984;i:189-90.

6 Bohen P, Huot S, Palfreyman MG. The relationship between GABA concentrations in brain and cerebrospinal ween GABA concentrations in brain
fluid. Brain Res 1979;167:297-305.

7 Grove J, Schechter PJ, Tell G, Morescaux C, Rumbach L. Increased gamma-aminobutyric acid (GABA) homocarnosine and $B$-alanine in cerebrospinal fluid of patients treated with $\gamma$-vinyl GABA (4-amino-hex,5-enoic acid). Life Sci 1981;28:2431-9.

8 Rimmer EM, Richens A, Milligan NM. A comparison of the effect of vigabatrin and sodium valproate on photosensitivity in epileptic patients. Epilepsy Res 1987;1:339-46.

9 Rimer EM, Kongola G, Richens A. Inhibition of the enzyme, GABA-aminotransferase in human platelets by vigabatrin: a potential antiepileptic drug. $\mathrm{Br} J$ Clin Pharmacol 1988:25:251-9.

10 Rimmer EM. Vigabatrin: a preliminary evaluation of a new anti-epileptic drug. MD Thesis, University of Liverpool, 1986

11 Muller RA, Lundberg DBA, Breese GR, Hedner J, Hedner $T$, Jonason J. The neuropharmacology of respiratory control. Pharmacol Rev 1982;34:255-85. 